\title{
The Research of Teaching Reform of National Music in Comprehensive University
}

\author{
XieChaoyin,AcademyofMusic, Linyi University, \\ Linyi, Shandong, P. R. China, 276000
}

\begin{abstract}
National music is the treasures of the motherland, which can improve the aesthetic taste,calculate the healthy personality and enhancepatriotic sentiments. However, national music did not receive due attention in comprehensive universities. There are many problems in national music teaching, such as unitary teaching method, insufficient practice training and low quality of teachers. This paper discusses these problems and gives responding suggestions in order to provide reference for relevant workers.
\end{abstract}

KEYWORDS: comprehensive university; national music; teaching reform

\section{Introduction}

National music refers to the traditional musicwith the morphological characteristics which is rooted in the national labor and social life.It is a reflection of the national culture, and represents the national spirit. The Chinese national music refers to the music which is made by Chinese nation and conforms tothe Chinese style.

In a comprehensive university, national music course is a required basic course of music majors. It is alsoone of the compulsory subjects of higher education postgraduate entrance examination. However, due to the influence of the western pop music, teachers often lack attention on national music course in the comprehensive university music majors. There is a trend to abandon the national music in comprehensive universities. The national music has very important positive significance of cultivating students' patriotism and healthy personality. Therefore, we must make greater efforts to carry forward the national culture, and deepen the national music teaching. It is an important task of the current music teaching in a comprehensive university.

\section{The Significance of National Music Teaching}

\section{A: Enhance the Aesthetic Taste}

As an organic part of the music education, national music reflects the Chinese nation unique aesthetic habits and aesthetic view in different forms of art. From the angle of aesthetics, Chinese national music mainly pay attention to the lateral aspect of the melody, focusing on shaping the artistic conception with the melody of music works, emphasizing the internal and external beauty of the integrity and unity, paying more attention to the educational value of musical works. It can bring inspiration, joy and souleducation to the students. The aesthetic education of music pays attention to the charm of style. Chinese ethnic music all has own characteristics. Xinjiang music is livelywithdance strong rhythm; Mongolian music melodious rhythm sonorous and broad. In the overall quality of education in the cultivation of aesthetic view of people, for the people's ideological quality, cultural quality, 
psychological quality, physical quality has special effects and irreplaceable role. Therefore, paying more attention to the national music education is the effective way to train the next generation of correct national music aesthetic.

\section{B: Cultivate Healthy Personality}

China national music can ease unhealthy psychological and cultivate sound personality. China traditional culture is often expressed as the concise and simple style. Chinese traditional national music often pursues stability and elegance. Because of pursuing the high official positions and riches, today's college students usuallybecome more frivolous and like quick success.Chinese national music can make people thought to simplify, forget the troubles, and makenegative emotion to positive emotions so as to form a healthy personality. Recovering one's original simplicity is indeed the highest purport Chinese life. It is also the highest interest Chinese art.Chinese national music can help students to cultivate healthy personalities.

\section{C: Strengthen Patriotic Sentiments.}

Mandatory indoctrination to college students ideological "patriotic" often leads to emotional conflict. However, effects of traditional music on college students aresubconsciousby environment and not forced indoctrination.National music enhances the students to the national sense of belonging to the state. If a person does not have a sense of belonging is terrible no matter in a family or a nation. Without family, there is no ultimate goal of life; without nations and countries, people are lonely and confused. But the students can directly experience the beautiful motherland and beautiful rivers and mountains of a countryin a pleasant music teaching process which can occurto national, national pride and love. Such a strong sense of belonging will strengthen patriotic sentiments.

\section{Problems of National Music Teaching in Comprehensive Universities}

\section{A: Teaching Method is Single}

In a comprehensive university, students now depressed and don't want to attend the class. The phenomenon often appears the national music classroom. The teacher boring sermon is one of the important reasons. Teachers often use the traditional teaching mode and single media music, lacking of information. The interaction with students is often little, which leads to a boring class. National music teachers should change the traditional teaching mode and use various teaching modes to attract students.

\section{B: Practice Training is Insufficient}

National music course can teach students not only national music theory, but also the combination of music theory and classroom practice based on the theory of music in comprehensive university. Music theory is boring and is very easy to affect students' interest in learning. Thus, a single music theory class will often reduce the enthusiasm of the students. It is appropriate to strengthen the combination of theory and practice. It undoubtedly can enhance students' learning interest, create a good classroom atmosphere, and achieve better teaching effect. Therefore, teachers must pay attention to the combination of theory and practice of classroom teaching of music in teaching music theory.

\section{C: Teachers' Quality is Comparatively Low}

The music teacher plays an irreplaceable role in national music teaching. Unfortunately, the teachers' quality in national music is low comparedwith teachers' western music quality. The teachers' level directly affects the teaching 
effect and teaching quality. Due to various aspects such as insufficient focus reasons, there are some problems such as age structure is not reasonable or the uneven quality of teachers is not high in Chinese comprehensive university national music teachers. In addition, the pay of the national music courses cannot attract outstanding music talents. Therefore, it is urgent to improve the national music quality of teachers.

\section{Reforms of National Music Teaching in Comprehensive Universities}

In view of the above problems of national music education in comprehensive universities, we adopt the following measures to reform:

\section{A: DiversifyTeaching Methods}

The most important reason for students appear bored in class is the single teaching method. Therefore, teachers should strain every nerve to change the traditional teaching mode and stereotypes to adopt some novel flexible teaching methods to attract students' attention and interest in learning. Teachers can use multi-media or IT technology to make the Chinese national music more interesting and attracting. For example, in the teaching of Mongolia folk music Gada Meiren, the teacher can change the past cramming teaching mode to use multi-media to achieve the interaction between students and students and teachers and students. Teachers can make courseware slides to put the past music related data into ethnic music material library. It is necessary to introduce the creation background of Gada Meiren and the hero Gada Meiren's stories to cultivate students' humanities accomplishment and help students to understand the music more accurately. In this way, students can grasp the rhythm and emotion in singing. Teachers should pay attention to the passion. When the music reaches a climax, teachers can sing out to get everyone's hearts resonate. Teachers can also ask the students to the podium to sing to active classroom atmosphere. Students get a rare opportunity to show themselves. They can feel the music is full of our ordinary life. It can arouse their study enthusiasm and initiative of national music to improve classroom efficiency.

\section{B: Strengthen Practice Training}

It is important to strengthen students' reading music ability and focus on the students'theme music solfeggio. We cannot only improve the students' intonation, rhythm and other aspects of the level,but also make students more deeply understand the music in this way. Teachers should strengthen the students' practical skills training. Teachers cultivate the students to music talents who can grasp the direction of skilled vocal singing and playing keyboard skill using national music education. In the traditional music skills teaching, teachers always take the attitude of the demonstration and guidance to students, while students in most of the time learn as a listener, imitators and practitioners. Teachers should break the traditional teaching pattern using transposition of teachers and students. In the transposition situations, students can freely share their feelings with each other. Everyone have the performance desire. When this desire is fulfilled by transposition, the students' learning desire and efficiency will be greatly to enhance.

\section{C: Improve Teachers' Quality}

The innovation and development of national music teaching is closely related to thequality of teachers. National music teachers should master certain national music theory, understand the analysis of some national modes, and distinguish artisticcharacteristics and style 


\section{CONCLUSIONS}

of music of all ethnics. The curriculum standard has clear regulations on the instrumental music teaching. National music teachers should grasp one or two pieces of simple instrument.Comprehensive universities should be committed to the national music teachers' professional quality. We can carry out the training to improve the teachers' national music theory knowledgeand put the music teaching innovation practice and theory organically. National music teachers should adopt the advanced teaching means and accumulate of experience to provide more efficient national music education. We should gradually improve the post appointment system. In addition, we should establish a fair and impartial evaluation system including university evaluation, department evaluation and student evaluation. We also should create a harmonious working environment to stimulate teachers'work enthusiasm and vitality. When the national music teachers' level is improved, the national music education quality will be raised.

\section{REFERENCE:}

[1]F Kun, K Pratt,A discussion on Chinese national musical traditions [J] A Thrasher - Asian Music, 2012, 9

[2]CHEN Yingshi. Ancient Chinese Banquet Music: Twenty-Eight Modes Re-studied [J]Journal of the Shanghai Conservatory of Music, 2004, 1

[3] TIAN Qing. Traditional Culture and Traditional Music of China [J] Journal of Nanjing Art Institute (Music \& Performance), 2007, 2

[4]He Jianhua. The Struggle for Culture: a sociological case study of the development of a national music curriculum[J], British Journal of Sociology of Education, 2004, 10 